\title{
The US economy since the crisis: slow recovery and secular stagnation*
}

\author{
Robert A. Blecker \\ Professor of Economics, American University, Washington, DC, USA
}

\begin{abstract}
The US economy has experienced a slowdown in its long-term growth and job creation that predates the Great Recession. The stagnation of output growth stems mainly from the depressing effects of rising inequality on aggregate demand, while both increased inequality and the delinkage of employment from output have their roots in profound structural changes to the US industrial structure and international position. Stagnation tendencies were temporarily offset by debt-financed household spending before the financial crisis, after which households became more financially constrained. Meanwhile, fiscal policy has shifted toward austerity while business investment has failed to keep up with the boom in corporate profits in spite of low interest rates. Slower US growth in turn exacerbates the global slowdown as it implies smaller injections of demand into global export markets.
\end{abstract}

Keywords: US economy, secular stagnation, jobless recovery, financial crisis, Great Recession

JEL codes: E20, E32, O51

\section{INTRODUCTION}

The recovery from the Great Recession of 2008-2009 has been the slowest and longest of any cyclical upturn in the US economy since the Great Depression of the 1930s. This slow and prolonged recovery was partly a result of the severity of the financial crisis that provoked the recession and the need to repair balance sheets in its aftermath (Koo 2013) as well as inadequate policy responses that failed to provide sufficient stimulus. Nevertheless, the sluggish recovery since 2009 also reflects a continuation of a longer-term growth slowdown, which was evidenced earlier in the jobless recovery and weak expansion after the milder recession of 2001. These two slow cyclical recoveries are symptomatic of underlying structural changes that have created a tendency toward secular stagnation in the US economy. I will argue that this tendency predates the financial crisis, but that its emergence was partly obscured by the financial bubbles and debt-led boom that preceded (and ultimately sparked) the crisis.

Before proceeding further, I would like to clarify that I am using the term 'secular stagnation' here in a descriptive sense, that is, to refer to a long-term tendency toward chronically slow average growth as opposed to (or in addition to) a sharp short-run downturn or slow cyclical recovery. In regard to theories of stagnation, my analysis is largely consistent with the 'post-Steindlian' theoretical perspective discussed by Hein (2016). I specifically do not mean to endorse the neoclassical view of secular stagnation in Summers $(2014 ; 2015)$, which focuses on a supposedly negative 'natural' (equilibrium, real) interest rate based on a loanable funds approach (see also Backhouse/Boianovsky 2016) - although my analysis does

* An earlier version of this paper was presented at the 19th FMM conference in Berlin in October 2015. The author would like to thank participants in the conference and Torsten Niechoj for comments on an earlier draft. Contact email for author: blecker@american.edu. 
share some common ground in regard to hysteresis effects and underlying causes (especially on the demand side). However, a full discussion of alternative theoretical perspectives on stagnation would be beyond the scope of this paper.

The rest of this article is organized as follows. Section 2 presents data that demonstrate the existence of a tendency toward secular stagnation in the US economy. Section 3 analyses the underlying causes of this tendency. Section 4 briefly discusses the implications of this tendency for the global economy. Section 5 concludes.

\section{INDICATORS OF SLOWER RECOVERIES AND STAGNATION TENDENCIES}

In arguing for the existence of a stagnation tendency in the US economy, I do not mean to deny that post-crisis US economic performance looks relatively good according to certain comparative benchmarks. First, the US economy did recover from the financial crisis of 2008 better than it did following the stock market crash of 1929, as emphasized by Bernanke (2015) and Furman (2015). As a result of the financial bail-outs, temporary fiscal stimulus and strong monetary policy responses - however much these may be legitimately criticized for various reasons (some of which are discussed below) - the US averted another Great Depression, and that is no small accomplishment. Nonetheless, avoiding a deep depression could be considered a low standard for modern economic performance, and does not preclude the possibility that the US has entered into a period of a chronically lower trend rate of growth.

Second, the US economy has recovered more quickly and more fully than most other advanced economies (especially Europe and Japan) since 2008-2009. Furman (2015) shows that US civilian employment and private domestic final purchases (the sum of consumption plus investment) had both recovered beyond their pre-recession peaks by 78 months after the recession began (January 2008), while the corresponding variables in the euro area still remained below their January 2008 levels after the same amount of time. But this too is a low bar, given the abysmal performance of the European and Japanese economies in recent years and their dysfunctional policy regimes (De Grauwe 2013; Garside 2016).

In terms of its own historical performance, however, the deterioration of US growth in recent years compared with earlier periods becomes apparent. As Table 1 shows, each US business cycle since the early 1980s has exhibited slower growth in the recovery and expansion phases than the one before it, whether we measure this by the initial recovery, trough-to-peak, or peak-to-peak. Moreover, the cyclical performance of employment has worsened even more than that of output. As demonstrated in Table 2, employment has taken much longer to recover to its pre-recession peaks in the last several business cycles (all of those since the early 1980s) compared with gross domestic product (GDP), which is why these episodes (starting with the 1990-1991 recession) have often been called 'jobless recoveries' (Papadimitriou et al. 2013). The 2001 recession was relatively shallow and short in terms of GDP, which took only 3 quarters to recover, but employment took 16 quarters to recover to its pre-recession peak. The 2008-2009 recession was, of course, much deeper and more prolonged in terms of output, but also involved the slowest recovery of employment since the Great Depression (25 quarters or more than 6 years, compared with 15 quarters or almost 4 years for GDP).

The worsening performance of employment compared with output is not simply a matter of employment being a lagging indicator in the business cycle (although it often is). The slower recovery of employment in the last few cycles is also symptomatic of a deeper and more long-term malaise affecting the US job market. Total US non-farm 
Table 1 Average annual growth rates of US GDP, last four business cycles

\begin{tabular}{lccc}
\hline Cycle (peak-trough-peak) & $\begin{array}{l}\text { First 4 years } \\
\text { (16 quarters) of } \\
\text { recovery }\end{array}$ & $\begin{array}{l}\text { Expansion } \\
\text { (trough to } \\
\text { peak) }\end{array}$ & $\begin{array}{l}\text { Entire cycle } \\
\text { (peak to peak) }\end{array}$ \\
\hline 1981Q3-1982Q4-1990Q3 $^{\text {a }}$ & 5.2 & 4.3 & 3.4 \\
1990Q3-1991Q1-2001Q1 $^{\text {a }}$ & 3.3 & 3.6 & 3.3 \\
2001Q1 $^{\text {a }-2001 Q 4-2007 Q 4 ~}$ & 3.2 & 2.8 & 2.6 \\
2007Q4-2009Q2-2015Q3 $^{\text {b }}$ & 1.9 & 2.2 & 1.2 \\
\hline
\end{tabular}

Notes: The dating of business cycles is taken from NBER (2010), except when GDP peaks differ from NBER peaks, then the GDP peak was used instead for the peak-to-peak calculations (entire cycle). a. The peak for GDP occurred in 2001Q2, but NBER dates the cycle peak in 2001Q1.

b. 2015Q3 is not a cycle peak, but it is the last period for which data were available.

Sources: US Bureau of Economic Analysis (BEA), National Income and Product Accounts (NIPA), table 1.1.1, quarterly growth expressed at seasonally adjusted annual rates, and author's calculations.

Table 2 Number of quarters required for real GDP and total non-farm employment to return to pre-recession peaks, all US business cycles since 1960

\begin{tabular}{lcc}
\hline Cycle (dated by previous peak) & Real GDP & Non-farm employment \\
\hline 1960Q2 & 3 & 6 \\
1969Q4 & 3 & 6 \\
1973Q4 & 8 & 6 \\
1980Q1 & 4 & 4 \\
1981Q3 & 7 & 9 \\
1990Q3 & 5 & 10 \\
2001Q1 & 3 & 16 \\
2007Q4 & 15 & 25 \\
\hline
\end{tabular}

Note: Cycle dating follows NBER (2010), except when peaks of GDP or employment differed from the NBER peaks, then the actual peaks of each variable were used.

Sources: US Bureau of Economic Analysis (BEA), National Income and Product Accounts (NIPA), table 1.1.6; US Bureau of Labor Statistics (BLS); and author's calculations.

employment grew by an average of 1.8 million per year in 1960-1979 and 2.0 million per year in 1980-1999. From 2000 through 2015, however, the average increase in employment was only about 762000 jobs per year, or roughly two-fifths of the rate achieved during the previous 4 decades. ${ }^{1}$ Thus, the stagnation in US employment began 7 years before the financial crisis broke out in 2007. The reduced rate of job creation is also reflected in the drop in the employment-population ratio for prime working-age workers (ages 25-54), which fell by 4.3 percentage points (from 81.5 to 77.2 per cent) between 2000 and 2015 (BLS). ${ }^{2}$ Also, the real income of the median US household began to grow

1. Author's calculations based on data from US Bureau of Labor Statistics (BLS). Data for 2015 include preliminary figures for October and November. More details on all data sources are given in the Appendix.

2. Data for 2015 are averaged for January-November. We prefer this age-specific measure to the overall employment-population ratio, which includes all age groups and hence does not control for the aging of the population. 
more slowly in the 1970s than it had in the previous 2 decades, and trended downward over the whole period 2000-2013. ${ }^{3}$

Thus, the deteriorating cyclical performance of the US economy since around $2000-$ especially in the labour market - has already translated into slower long-term growth trajectories for output, employment and family incomes. If one follows Kalecki's (1971: 165) dictum that 'the long-run trend is but a slowly changing component of a chain of shortperiod situations; it has no independent entity', then the succession of ever-worsening cycles (in terms of falling GDP growth rates and slower recovery of employment) implies a corresponding worsening of the long-term trend. Even if one takes the most conventional measure of average annual GDP growth, this registered only a 1.9 per cent rate from 2000 to 2015 compared with 3.3 per cent in 1980-1999 and 3.9 per cent in 1960-1979 4 - and, as noted above, the long-term trends in employment and median family incomes have deteriorated even more.

Alternatively, if one views long-run growth as driven by the creation of productive capacity on the supply side, as in most classical and neoclassical theories, then one has to confront the mounting evidence for what has become known as 'hysteresis': that is, the protracted period of depressed actual growth has diminished the growth of potential output for the foreseeable future. A team of Federal Reserve economists (speaking of course for themselves and not for the Board of Governors of the Federal Reserve System) has stated flatly that 'a significant portion of the recent damage to the supply side of the economy plausibly was endogenous to the weakness in aggregate demand' (Reifschneider et al. 2015: 71). They and other economists (for example, Ball 2014; Blanchard et al. 2015) have attributed these hysteresis effects to depressed investment in both physical and human capital since the 2008-2009 crisis. ${ }^{5}$ According to these analyses, such persistent effects of the slow recovery from the crisis underlie the dramatically lowered projections of future full-capacity output by economic forecasters, with the implication that depressed aggregate demand has endogenously limited the expansion of aggregate supply.

\section{CAUSES OF SECULAR STAGNATION}

\subsection{Demand-side causes}

In terms of underlying causes, the prime culprit in the weakening of aggregate demand is the worsening of inequality in US society, which impacts the largest component of GDP: consumption. Over the past few decades, inequality has increased along multiple dimensions, including larger gaps between more and less educated workers, a falling labour share of national income and a widening of the gaps between different quintiles or percentiles in the household distribution of income (Mishel et al. 2012).

One important driver of widening inequality is the slower growth of real wages and benefits compared to labour productivity. Real hourly compensation closely tracked output per hour until the 1970 s, but has grown at a much slower rate than productivity since

3. See chart 'Real median family income, 1947-2013 (2013 dollars)', which updates (as of 23 September 2014) figure 2A in Mishel et al. (2012), http://www.stateofworkingamerica.org/ chart/swa-income-figure-2a-real-median-family/.

4. Data from US Bureau of Economic Analysis (BEA) - see the Appendix. Data for 2015 are for the first three quarters.

5. Depressed business investment and residential construction are discussed below. The erosion of human capital is attributed by these authors to the impact of prolonged unemployment, exit from the labour force or reduced ability to finance education since the crisis. 
then (BLS). As a result, there has been a tendency for the labour share of corporate income to decline, although this tendency did not clearly emerge until somewhat later as a result of differences in the price indexes used in calculating real output and compensation. The nonfinancial corporate labour share in nominal terms exhibited the standard 'stylized fact' of cyclical variations along a roughly constant trend up to the late 1990s, but has declined sharply since 2000 (BLS). ${ }^{6}$

In regard to the personal distribution of income, family income tended to increase at roughly equal rates for all quintiles during the period 1947-1979. Since then, however, the changes have been entirely in a disequalizing direction, as income growth rates have been higher in each higher quintile compared with the one below it - and highest for the top 5 per cent (Mishel et al. 2012). From 2007-2013, only the top 5 per cent had any positive gains whatsoever; all other quintiles lost, and the lower the quintile, the greater were the income losses. ${ }^{7}$ Also, the data in Piketty (2014) reveal the tremendous increases in the income shares of the top 1 per cent and top 0.01 per cent in the US since the 1970s.

Based on post-Keynesian or neo-Kaleckian theory, such increasing inequality would be expected to have a depressing effect on consumption, which is the largest component of aggregate demand. Many studies (for example, Onaran et al. 2011; Onaran/Galanis 2012) have confirmed that US consumption is an increasing function of the wage share of national income. In addition, Cynamon/Fazzari (2015) have shown that, by correcting the US national income accounts for various misleading imputations and focusing on actual expenditures of households for consumption and housing, a clear correlation emerges between income distribution and expenditure rates. Specifically, Cynamon/Fazzari show that worsening inequality between the top 5 per cent and the bottom 95 per cent has contributed to a sharp weakening of correctly measured household spending.

Of course, US consumption expenditures remained quite robust throughout the 1990s and up until the outbreak of the financial crisis in 2007. However, the negative impact of widening inequality on consumption was offset in the late 1990s and early 2000 s by massive increases in household debt, which permitted middle-class families to increase their spending in spite of stagnant incomes, as argued by numerous economists (see Palley 2012; Hein/Mundt 2013; Setterfield 2013; Cynamon/Fazzari 2015; among others). Most of the growth in household debt occurred in residential mortgages, which contributed to the housing boom/bubble, but some of the funds borrowed against home equity could be used directly or indirectly to pay for additional consumption. Meanwhile, real housing prices climbed by 60 per cent in the decade leading up to their peak in 2006 and then cratered during the ensuing financial crisis (Blecker 2014: 702). This debt-led consumption-and-housing boom was of course unsustainable, and the financial crisis put an end to the ability of US households to sustain such high levels of consumption and housing expenditures via borrowing.

Now, one might think that the rise in the profit share in the 2000s (which is the mirror image of the fall in the wage share discussed earlier) might have led to increases in investment that could have compensated for the weakness of consumption, especially during the recovery from the 2008-2009 crisis. In reality, however, the share of gross business fixed investment in GDP has trended downward since 2000, in spite of a sharp increase in the profit share of corporate value added since that time (see Figure 1). Of course, investment

6. Prior to 2000, the labour share for nonfinancial corporations tended to rise in the latter part of cyclical expansions and then decline after recession troughs.

7. See chart 'Average family income growth, by income group, 1947-2013', which updates (as of 24 September 2014) figure 2C in Mishel et al. (2012), http://www.stateofworkingamerica.org/ chart/swa-income-figure-2c-average-family-income/. 


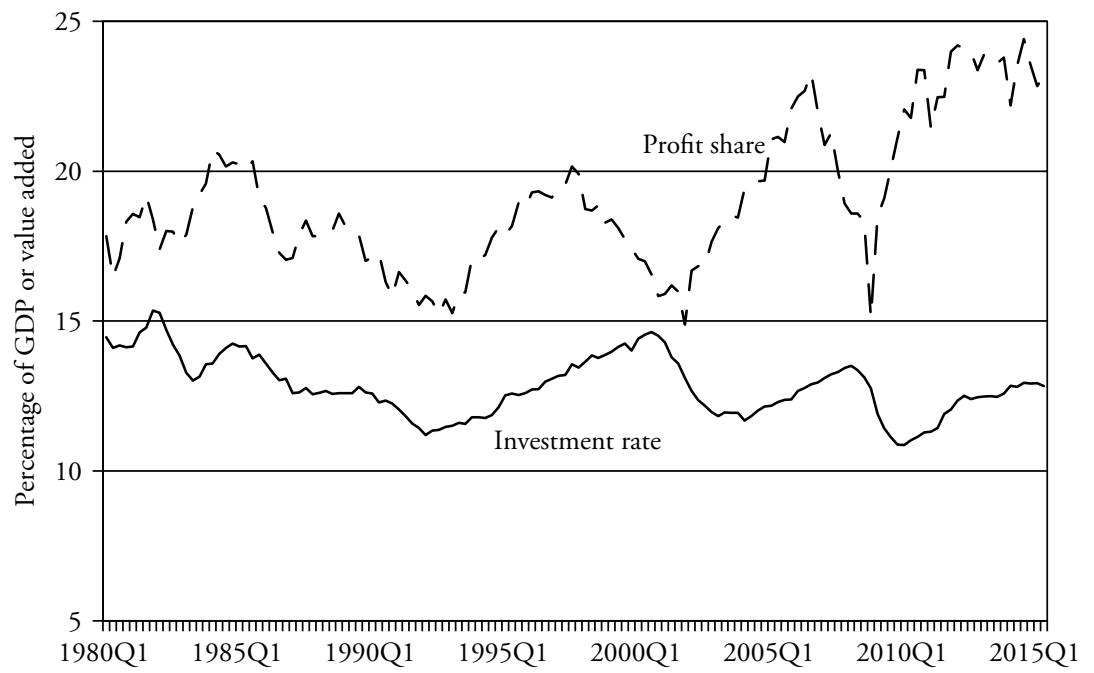

Sources: US Bureau of Economic Analysis (BEA), National Income and Product Accounts (NIPA), tables 1.1.5 and 1.14; US Bureau of Labor Statistics (BLS); and author's calculations.

Figure 1 US corporate profit share (net operating surplus as a percentage of corporate value added) and business investment rate (gross fixed non-residential investment as a percentage of GDP), quarterly, 1980Q1 to 2015Q2

does follow profitability in terms of short-run cyclical fluctuations, with some lags, but the longer-term trends in these two variables are moving in opposite directions, and investment has not shown the same kind of robust increase during the post-2009 recovery that one sees in profits. Furthermore, this weakening of investment has occurred despite interest rates that have been at record lows as well as profits that have soared to record highs. Evidently, firms are responding mostly to the lack of demand growth in making their investment decisions, which shows that a strong accelerator effect dominates in the investment function over profitability or cost-of-capital factors, especially in the long term (see Chirinko et al. 2011; Schoder 2013).

Meanwhile, housing investment - which is generally more sensitive to interest rates than business investment - had only recovered to levels that would normally be typical of a recession as of 2014-2015. ${ }^{8}$ The still-depressed level of residential construction is, of course, a reflection of the severity of a financial crisis in which the housing sector was the epicentre. But the continued weakness of housing and business investment combined also demonstrates the weak impact of the monetary policies (both conventional policies, which reduced short-term interest rates to the 'zero lower bound' until December 2015, and 'quantitative easing' policies designed to lower long-term yields) that have been the main instruments for trying to restore economic growth since the crisis. While those policies may have helped to rescue the financial sector and prevent a more severe depression, they have failed to engender a robust recovery of either business investment or housing construction.

Unfortunately, fiscal policy has not stepped up to compensate for the weaknesses of private spending and the relatively ineffective monetary stimulus during the post-crisis period.

8. Based on author's analysis of data from BEA and US Census Bureau; see Appendix for sources. 


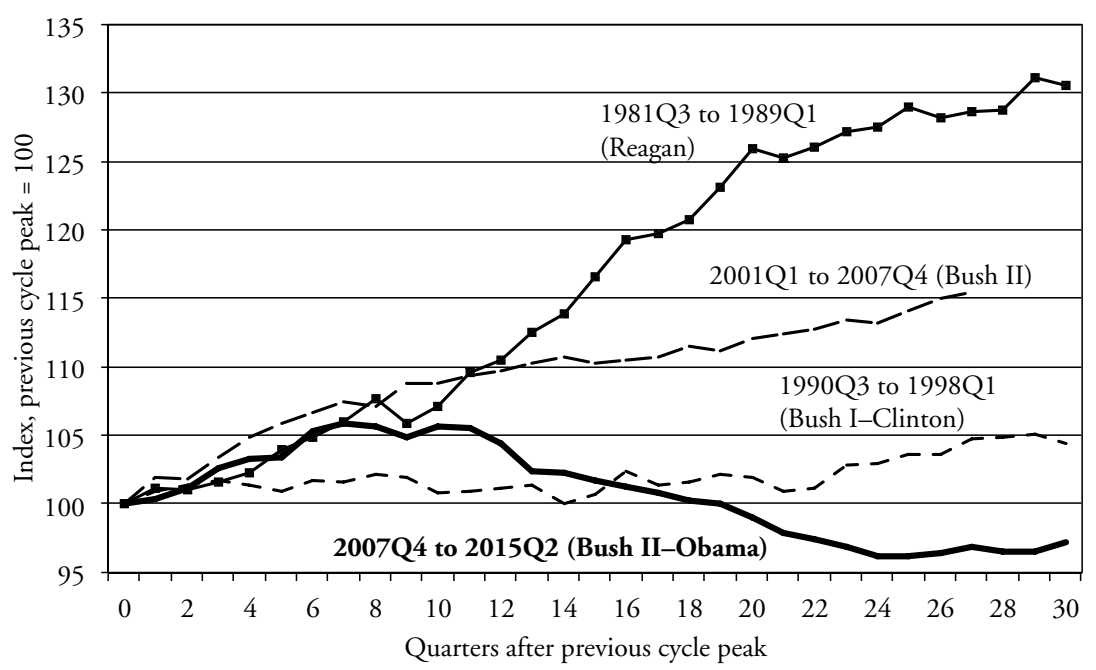

Source: US Bureau of Economic Analysis (BEA), National Income and Product Accounts (NIPA), table 1.1.6, and author's calculations.

Figure 2 Real US government consumption expenditures and gross investment, first 30 quarters of the last four recessions and recoveries

Of course, automatic fiscal stabilizers continued to operate, as seen especially in the sharp rise in the US budget deficit in 2008-2009. But only small and short-lived fiscal stimulus policies were adopted under both the Bush and Obama administrations (although the Obama stimulus of 2009-2010 was larger and more consequential than the minuscule Bush tax rebate of 2008). The government deficit peaked at about 13 per cent of GDP in the third quarter of 2009 (BEA), mostly as a consequence of the recession rather than the Obama stimulus. Although this surely helped to prevent the economy from falling into a worse depression, it also led to a political reaction that brought ultra-conservative Republicans into a dominant position in the Congress following the 2010 elections. Democrats were not immune to the anti-deficit hysteria, but focused on raising tax rates for the wealthy rather than cutting spending. From 2011-2015, various austerity measures (spending cuts or ceilings, including but not limited to the infamous 'sequester', as well as reversals of some earlier tax cuts) were imposed as a consequence of a series of politically provoked legislative crises and last-minute compromises reached between Congressional Republicans and the Obama administration. As a result, real federal government spending actually fell below pre-recession peak levels in 2012-2015, unlike in any other recent recovery period (see Figure 2). Thus, austerity policies started putting a severe fiscal drag on the US economy at a time when the recovery was far from complete.

\subsection{Structural causes}

Not all of the causes of stagnation tendencies in the US economy lie on the demand side, and some of the demand-side shifts may reflect deeper underlying causes. Especially, the rise in inequality and the increasing gap between output and employment growth need to be explained. A full analysis of the causes of the rise in inequality would be beyond the 
scope of this article. However, there are certain structural changes in the US economy that have been important contributing factors to both the rise in inequality and the emergence of stagnation tendencies, especially in regard to employment and wages.

The most relevant type of structural change in this regard is the decline in US manufacturing production and the concomitant rise of the service sector. Declining employment in manufacturing has been driven by a worsening trade deficit in manufactured goods and the vertical disintegration of manufacturing production - the offshoring of intermediate goods and assembly operations to lower-wage locations (see Palley 2014). The US trade deficit in manufactures, which averaged about 6 per cent of domestic value added in the manufacturing sector in the 1980s, fell to an average of 25 per cent in the period 2000-2014. ${ }^{9}$ What remains of US manufacturing needs relatively little labour, as the most labour-intensive operations have been offshored to other countries as much as possible.

This transformation of the US manufacturing sector has a two-sided effect on labour markets and inequality. On the one hand, it puts downward pressure on wages, especially because most of the growth in manufactured imports has come from lower-wage countries such as China and Mexico. On the other hand, the offshoring of manufacturing jobs directly contributes to the decline in employment in this sector, which has fallen by 5 million or nearly 30 per cent since 2000 (BLS). One recent study finds that increased imports from China alone cost the US somewhere in the range of about 2.0-2.4 million jobs between 1999 and 2011 (Acemoglu et al. 2016; see also Scott 2011; Autor et al. 2016). Because manufacturing jobs tend to pay better than jobs in other sectors on average, it is mainly high-wage employment that is reduced as manufacturing shrinks and service activities expand. Most of the expansion in services employment in recent years has been concentrated in lower-paying occupations.

In addition, there are two other ways in which the rise of services as a share of GDP has contributed to weakening the employment impact of output growth. In regard to business cycles, Olney/Pacitti (2015) argue that a growing proportion of service industries implies a slower recovery of employment after a recession for two reasons: (i) service producers don't need to restock inventories in anticipation of increased demand during a recovery; and (ii) many services are nontradeable, which implies that exports don't provide as big a boost in the recovery as they do for goods producers. Using US state-level data, Olney/ Pacitti find that a rising share of nontradeable services has contributed significantly to longer recoveries of employment after a cycle trough.

For the longer term, Basu/Foley (2013) observe that different service sectors are not equivalent in terms of their contributions to output and employment. The service sectors that have 'measureable value added' create jobs in some proportion to their value added as reported in the national income accounts. But other services don't have measurable value added; instead, their output is imputed in the national income accounts based on income received and is not closely related to the amount of employment generated. The service sectors without measureable value added (including, notably, financial services) have grown to the point where they now account for more than half of GDP. When these sectors' reported output grows, they don't necessarily create jobs in proportion. As a result of this and other structural changes, employment growth is increasingly delinked from reported output (GDP) growth. According to Papadimitriou et al. (2013: 10), a 1 per cent increase in US GDP led to a 0.528 per cent increase in employment in the period 1982Q4-1990Q2, but only a 0.42 per cent increase in the latter in 2001Q4-2007Q3 and 0.288 per cent in 2009Q2-2012Q4.

9. Author's calculations based on data from the US Census Bureau and BEA. Trade balances for manufacturing in 1978-1991 are author's extrapolations. 


\section{GLOBAL REPERCUSSIONS}

Before the 2008-2009 crisis, global growth was sustained by a triangular pattern of trade imbalances, financial flows and demand transmission among three groups of countries: the deficit countries or net demand generators (for example, US, UK), the manufacturing exporters (for example, China, Germany) and the primary commodity exporters (for example, Russia, Brazil). Of course, there were also reciprocal demand flows in the opposite directions between these various groups of countries as well as within them (including major imbalances within the euro area), but at a global level net excess demand largely flowed from the deficits (and borrowing) of the main demand-generating countries toward the surplus countries that were the chief exporters of manufactured goods and primary commodities (Blecker 2013; 2014).

During the precrisis boom, the manufacturing exporters as well as the resource exporters ultimately relied on debt-driven household demand from the deficit countries to support their export-led growth (Hein/Mundt 2013; Palley 2014). The fallacy in this strategy is that it eventually weakened the very source of its own dynamic by undermining employment and incomes in the deficit nations that ultimately generate the demand, especially through the reductions in manufacturing employment and downward pressures on wages noted earlier.

Using the US current-account deficit as a measure of the net demand impulse that the US imparts to the rest of the world, this deficit decreased to about 2-3 per cent of GDP in 2014-2015, only about half as much as in 2006-2007 before the crisis (BEA). The US deficit has been reduced partly because of weak domestic demand, and also because the large trade deficit in manufactures has been partly offset by increased surpluses in services and investment income. Smaller US current-account deficits imply less transmission of demand stimulus to the rest of the world. For all the reasons discussed here, the US is not likely to be as strong a generator of global demand in the foreseeable future as it was before 2008. Moreover, the current (as of 2016) slowdown in growth in many regions that are major markets for US exports (for example, the euro area, Latin America) is having negative repercussion effects on US growth prospects. To avoid sustained global deflationary pressures, therefore, the surplus countries will need to generate more of their own demand (both internally and reciprocally) and not rely so much on the US or other deficit countries to be the locomotives of growth in the foreseeable future.

\section{CONCLUSIONS}

The US economy is currently locked into a trajectory that implies a tendency toward secular stagnation as a result of the following (closely interrelated) factors:

- the underlying weakness of household demand due to stagnant real wages and increasing inequality, no longer offset by unsustainable borrowing;

- structural changes leading to reduced employment generation in proportion to output growth and a shrinkage of high-wage manufactures;

- weak private sector domestic investment in spite of record profits and low interest rates;

- political gridlock and the imposition of austerity in fiscal policy; and

- reverberations from foreign slowdowns - especially in the euro area and the resource exporters, which are key destinations for US exports.

However, there is an important difference between identifying a tendency toward secular stagnation and making a prediction that (or when or for how long) it will actually occur. 
Any such prediction must always be conditional on the absence of counteracting forces. For example, we cannot discard the possibility of a new technological wave that generates an economic boom, or the alternatives of a new financial bubble or renewed debt-led spending. Indeed, we should not underestimate either the ingenuity of Wall Street (which was rescued by the bail-outs and largely untamed by post-crisis 'reforms') or the short memories of lenders, borrowers and policy-makers. Of course, such a transitory boom would not be any more sustainable than the previous bubbles or debt-led expansions.

We must also recognize that long-term trends can be interrupted by short-term deviations. As of early 2016, there were conflicting signals about US economic prospects. On the one hand, there were some signs that the US had finally entered a self-sustaining expansion, which had motivated the Federal Reserve's decision to start raising short-term interest rates in December 2015. On the other hand, there appeared to be increasing risks of a new recession because of factors such as the rising value of the dollar (itself partly a function of US monetary tightening), slowing growth in other countries including major US export markets, and volatility in global stock markets. Normally complacent institutions such as the Organisation for Economic Co-operation and Development (OECD) were giving dire warnings of a worsening global slowdown in the absence of new fiscal stimulus policies (OECD 2016).

One factor that provides some glimmer of hope is the emergence of pressures for an enhanced role for the public sector on the centre-left of the US body politic. Both progressive forces and some mainstream elements in the Democratic Party are calling for a new program of fiscal expansion focused on expenditures on infrastructure investment, solar and wind energy, public education, and other social and environmental needs. On the other hand, Republican politicians continue to rehash various conservative schemes for slashing social spending and benefits while further cutting the taxes of the wealthy and bolstering military spending; as usual, most of these 'plans' don't add up in terms of the claimed deficit reduction. Thus, much depends on the outcome of the presidential election in November 2016 and the specific fiscal policies pursued thereafter. But renewed fiscal expansion and increased public investment - even if implemented - will not make a dent in the long-term trends in inequality and stagnation unless they are sufficient to create a period of sustained high employment leading to a recovery of wages relative to productivity, and unless complementary measures are taken to counteract the structural changes that have fostered greater inequality and jobless growth.

\section{REFERENCES}

Acemoglu, D., Autor, D., Dorn, D., Hanson, G.H., Price, B. (2016): Import competition and the great US employment sag of the 2000s, in: Journal of Labor Economics, 34(1, pt. 2), S141-S198.

Autor, D., Dorn, D., Hanson, G.H. (2016): The China shock: learning from labor market adjustment to large changes in trade, National Bureau of Economic Research (NBER), Working Paper No 21906, January.

Backhouse, R.E., Boianovsky, M. (2016): Theories of stagnation in historical perspective, in: European Journal of Economics and Economic Policy: Intervention, 13(2), 147-159.

Ball, L. (2014): Long-term damage from the Great Recession in OECD countries, in: European Journal of Economics and Economic Policies: Intervention, 11(2), 149-160.

Basu, D., Foley D.K. (2013): Dynamics of output and employment in the US economy, in: Cambridge Journal of Economics, 37(5), 1077-1106.

Bernanke, Ben S. (2015): The Courage to Act: A Memoir of a Crisis and its Aftermath, New York: Norton.

Blanchard, O., Cerutti, E., Summers, L. (2015): Inflation and activity: two explorations and their monetary policy implications, Peterson Institute for International Economics, Working Paper No WP 15-19, November. 
Blecker, R.A. (2013): Global imbalances and the U.S. trade deficit, in: Cynamon, B.Z., Fazzari, S.M., Setterfield, M. (eds), After the Great Recession: The Struggle for Economic Recovery and Growth, Cambridge, UK: Cambridge University Press.

Blecker, R.A. (2014): Economic stagnation in the United States: underlying causes and global consequences, in: Brazilian Journal of Political Economy, 34(4), 689-725.

Chirinko, R.S., Fazzari, S.M., Meyer, A.P. (2011): A new approach to estimating production function parameters: the elusive capital-labor substitution elasticity, in: Journal of Business and Economic Statistics, 29(4), 587-594.

Cynamon, B.Z., Fazzari, S.M. (2015): Rising inequality and stagnation in the US economy, in: European Journal of Economics and Economic Policies: Intervention, 12(2), 172-182.

De Grauwe, P. (2013): Design failures in the Eurozone: can they be fixed?, LSE Europe in Question Discussion Paper Series No 57/2013, February.

Furman, J. (2015): It could have happened here: the policy response that helped prevent a second great depression, Macroeconomic Advisers' 25th Annual Washington Policy Seminar, 9 September (expanded version of remarks).

Garside, W.R. (2016): Did Japan's high-growth success foster persistent stagnation?, in: European Journal of Economics and Economic Policy: Intervention, 13(2), 189-202.

Hein, E. (2016): Secular stagnation or stagnation policy? A post-Steindlian view, in: European Journal of Economics and Economic Policy: Intervention, 13(2), 160-171.

Hein, E., Mundt, M. (2013): Financialization, the financial and economic crisis, and the requirements and potentials for wage-led recovery, in: Lavoie, M., Stockhammer, E. (eds), Wage-led Growth: An Equitable Strategy for Economic Recovery, Basingstoke, UK: Palgrave Macmillan, 153-186.

Kalecki, M. (1971): Selected Essays on the Dynamics of the Capitalist Economy, 1933-1970, Cambridge, UK: Cambridge University Press.

Koo, R.C. (2013): Balance sheet recession as the 'other half of macroeconomics, in: European Journal of Economics and Economic Policies: Intervention, 10(2), 136-157.

Mishel, L., Bivens, J., Gould, E., Shierholz, H. (2012): State of Working America, 12th edn, Ithaca, NY: Economic Policy Institute/Cornell University Press.

NBER (National Bureau of Economic Research) (2010): US Business Cycle Expansions and Contractions, Cambridge, MA: NBER, last updated 20 September 2010, URL: http://www.nber.org/ cycles.html.

Olney, M.L., Pacitti, A. (2015): The rise of services and the lengthening of economic recovery, BEHL Working Paper WP2013-04, revised May 2015.

Onaran, Ö., Galanis, G. (2012): Is aggregate demand wage-led or profit-led? National and global effects, Conditions of Work and Employment Series No 40, International Labour Office, Geneva.

Onaran, Ö., Stockhammer, E., Grafl, L. (2011): The finance-dominated growth regime, distribution, and aggregate demand in the US, in: Cambridge Journal of Economics, 35(4), 637-661.

OECD (Organisation for Economic Co-operation and Development) (2016): Stronger growth remains elusive: urgent policy response is needed, Interim Economic Outlook, 18 February, URL: //www.oecd.org/economy/economicoutlook.htm.

Palley, T.I. (2012): From Financial Crisis to Stagnation: The Destruction of Shared Prosperity and the Role of Economics, Cambridge, UK: Cambridge University Press.

Palley, T.I. (2014): Global imbalances: benign by-product of global development or toxic consequence of corporate globalization? in: European Journal of Economics and Economic Policies: Intervention, 11(3), 250-268.

Papadimitriou, D.B., Hannsgen, G., Nikiforos, M. (2013): Is the link between output and jobs broken? Levy Institute, Strategic Analysis, March.

Piketty, T. (2014): Capital in the Twenty-First Century, Cambridge, MA: Harvard University Press.

Reifschneider, D., Wascher, W.L., Wilcox, D. (2015): Aggregate supply in the United States: recent developments and implications for the conduct of monetary policy, in: IMF Economic Review, 63(1), 71-109.

Schoder, C. (2013): Credit vs. demand constraints: the determinants of US firm-level investment over the business cycles from 1977 to 2011, in: North American Journal of Economics and Finance, 26(1), 1-27. 
Scott, R.E. (2011): The China toll: growing U.S. trade deficit with China cost more than 2.7 million jobs between 2001 and 2011, with job losses in every state, Economic Policy Institute, Briefing Paper No 345.

Setterfield, M. (2013): Wages, demand, and U.S. macroeconomic travails: diagnosis and prognosis, in: Cynamon, B.Z., Fazzari, S.M., Setterfield, M. (eds), After the Great Recession: The Struggle for Economic Recovery and Growth, Cambridge, UK: Cambridge University Press.

Summers, L.H. (2014): U.S. economic prospects: secular stagnation, hysteresis, and the zero lower bound, in: Business Economics, 49(2), 65-73.

Summers, L.H. (2015): Demand side secular stagnation, in: American Economic Review: Papers and Proceedings, 105(5), 60-65.

\section{APPENDIX: DATA SOURCES}

US Bureau of Economic Analysis (BEA), National Income and Product Accounts (NIPA), data release of 22 December 2015 and earlier releases, www.bea.gov. Gross domestic product (GDP) and its components (including residential and business investment, government expenditures, net exports), corporate value added and profits, and related measures.

US Bureau of Economic Analysis (BEA), GDP by industry, data release of 23 April 2015, www.bea. gov. Manufacturing value added.

US Bureau of Economic Analysis (BEA), International transactions accounts, data release of 17 September 2015, www.bea.gov. Current-account balance and its components.

US Bureau of Labor Statistics (BLS), Employment, Hours, and Earnings from the Current Employment Statistics survey (National), downloaded 24 December 2015, www.bls.gov. Employment and wage data, total or by industry.

US Bureau of Labor Statistics (BLS), Major Sector Productivity and Costs, downloaded 27 September 2015, www.bls.gov. Labour productivity, real hourly compensation and labour share index.

US Bureau of Labor Statistics (BLS) (2016), Labor Force Statistics from the Current Population Survey, downloaded 5 January 2016, www.bls.gov. Unemployment rate, labour force participation, employment-population ratio.

US Census Bureau, New Residential Construction, downloaded 25 September 2015, www.census. gov. Housing units started.

US Census Bureau, US International Trade in Goods and Services, FT900, various years, downloaded 3 October 2015, www.census.gov. Manufacturing trade data. 